\title{
Post harvest technology and value addition of tomatoes
}

\author{
P. Geetha and C. Indhu Rani
}

Key Words : Post harvest Technology, Value addition, Tomatoes

How to cite this article : Geetha, P. and Indhu Rani, C. (2020). Post harvest technology and value addition of tomatoes. Food Sci. Res. J., 11(2): 217-229, DOI : 10.15740/HAS/FSRJ/11.2/217-229.Copyright@ 2020: Hind Agri-Horticultural Society.

Author for correspondence :

P. Geetha, Centre for Post Harvest Technology, Agricultural Engineering College and Research Institute, Tamil Nadu Agricultural University, Coimbatore (T.N.) India

Email: geethapadmanaban2@gmail.com

Associate Authors' :

C. Indhu Rani, Department of Floriculture and Landscaping Architecture, Horticulture College and Research Institute for Women, (TNAU), Trichy, Coimbatore (T.N.) India 